\title{
A semiochemical from larval food influences the entrance of Varroa destructor into brood cells
}

\author{
Francesco NAZZI*, Norberto MilAni, Giorgio Della VedovA \\ Dipartimento di Biologia Applicata alla Difesa delle Piante, Università di Udine, via delle Scienze 208, \\ 33100 Udine, Italy
}

(Received 3 April 2003; revised 27 October 2003; accepted 3 December 2003)

\begin{abstract}
Chemical stimuli responsible for the biological activity of bee larval food on Varroa destructor were studied both in the laboratory and under natural conditions. Loss of activity after neutralization and air entrainment experiments suggested that active substances were acidic and volatile. Linear, branched and aromatic carboxy-acids, as well as hydroxy-acids, were identified by GC-MS and SPME-GC-MS analysis in organic larval food extracts. The low molecular weight carboxy-acids identified were tested in a laboratory assay using a four-well arena. All the acids tested were inactive with the exception of 2hydroxyhexanoic acid; comparison with related compounds and dose-response studies confirmed the activity of this acid at 10 and $100 \mathrm{ng}$ per well showing that this is a semiochemical for the mite. One hundred nanograms of 2-hydroxyhexanoic acid applied to worker brood cells before capping increased by $36 \%$ the number of mites per cell in the treated brood compared to the control cells.
\end{abstract}

\section{2-Hydroxyhexanoic acid / cell invasion / larval food / semiochemical / Varroa destructor}

\section{INTRODUCTION}

Varroa destructor Anderson \& Trueman (Acarina Varroidae) enters bee brood cells 0-40 hours before capping (Boot et al., 1992). Signals triggering cell invasion have been investigated; research has focused on the possible release of semiochemicals by the bee larva and has led to the identification of compounds that are active on the mite in the laboratory (Le Conte et al., 1989; Rickli et al., 1992, 1994; Aumeier and Rosenkranz, 1995). However, the biological activity of some of them was not confirmed by later studies (Rosenkranz, 1993; Zetlmeisl and Rosenkranz, 1994) and none has been shown to increase the attractiveness of brood cells under natural conditions. Furthermore, most of these compounds are widespread inside the hive (Bee World, 1975; Crane, 1979; Blomquist et al., 1980; Tulloch, 1980; Francis et al., 1985;
Marcucci, 1995), thus lacking the specificity needed to act as a signal for the invading mites.

Moreover it was noted that, when offered a choice between bee larvae from nearly capped brood cells and adult nurse bees, under laboratory conditions, $V$. destructor prefers the latter (Kraus, 1993; LeDoux et al., 2000). As the mite is carried to the brood cell by a nurse bee, the preference for nurse bees over bee larvae was a puzzling result that prompted the research on further stimuli involved in the process of cell invasion by the mite. Recently Nazzi et al. (2001) demonstrated the biological activity of larval food and its acetone and ether extracts on $V$. destructor by using a bioassay in which the behaviour of the mite was studied in a four-well arena. The biological activity of larval food extracts was later confirmed by Calderone and Lin (2001) using a different bioassay.

\footnotetext{
* Corresponding author: francesco.nazzi@ uniud.it
} 
The aim of this study was to identify semiochemicals contained in bee larval food that are involved in the invasion of brood cells by the parasite.

\section{MATERIALS AND METHODS}

\subsection{Biological material}

The worker bee larvae and the adult females of $V$. destructor used in all the experiments came from untreated local Apis mellifera L. colonies maintained in Udine (north-eastern Italy). Previous studies indicated that the local bee population consists of hybrids between A .m. ligustica and A. m. carnica (Comparini and Biasiolo, 1991; Nazzi, 1992).

The mites and bee larvae were obtained from brood cells capped $0-15$ hours before, according to Chiesa et al. (1989).

Larval food was extracted with a small spatula from drone cells containing either a fourth $(14)$ or fifth instar larva (l5) and kept at $-20{ }^{\circ} \mathrm{C}$ in sealed vials until used. Storage never lasted longer than five months.

\subsection{Extraction of larval food and isolation}

For extraction, $1 \mathrm{~g}$ of larval food was smeared with a spatula inside a conical test tube and about $5 \mathrm{~mL}$ of solvent were added. Both acetone and diethyl ether were used for the extraction. After 1 hour the tube was centrifuged until the larval food residue settled and the supernatant was transferred to another tube. Half of the extract was bio-assayed as such, half was neutralized with sodium bicarbonate and then bioassayed. The acetone extract was neutralized by adding an excess of $\mathrm{NaHCO}_{3}$; after shaking, the mixture was allowed to settle, then the supernatant was taken and tested in the bioassay. The ether extract was mixed with an equal volume of a saturated water solution of $\mathrm{NaHCO}_{3}$; after shaking, the ether fraction was taken, dehydrated with magnesium sulphate and tested in the bioassay. After acidification the water fraction was extracted with ether to recover the carboxy-acids and the extract tested in the bioassay.

The volatile compounds released by larval food were also extracted by air-entrainment. Two hundred milligrams of larval food were placed in a glass vessel; air purified by passage through an activated molecular sieve and charcoal was drawn at $100 \mathrm{~mL} / \mathrm{min}$ through the vessel. Volatiles were entrained over a 5 hours period onto Porapak Q. Collected volatiles were desorbed from the Porapak by elution with ether; the resulting extract was then concentrated under nitrogen and tested in the laboratory bioassay.

\subsection{Identification}

The compounds present in the larval food extracts were identified with a Varian 3400 gas-chromatograph coupled to a Varian Saturn 2000 mass spectrometer (GC-MS). The column (CP-SIL 8, $30 \mathrm{~m} \times$ $0.25 \mathrm{~mm}$ ID, film thickness: $0.25 \mu \mathrm{m}$ ) was maintained at $40^{\circ} \mathrm{C}$ for $1 \mathrm{~min}$ then programmed to $320^{\circ} \mathrm{C}$ at $10{ }^{\circ} \mathrm{C} / \mathrm{min}$. The carrier gas was helium (flow: $1 \mathrm{~mL} / \mathrm{min})$.

The ether extract was also analysed after derivatization with hexamethyldisilazane: trimethylchlorosilane 2:1 (Sweeley et al., 1963).

The volatile compounds released by larval food were analysed by means of solid phase microextraction GC-MS (SPME-GC-MS) using a polyacrilate fibre $(85 \mu \mathrm{m})$; the fibre was exposed for 1 hour to the volatiles emitted by $500 \mathrm{mg}$ of larval food contained in an air-tight vial maintained in a warm bath at $35^{\circ} \mathrm{C}$. The analysis method was the same as above, except for the column upper temperature $\left(250{ }^{\circ} \mathrm{C}\right)$.

In all cases identification was based on the comparison of the mass spectra and the retention time with that of authentic standards analysed under the same chromatographic conditions.

No quantitative analysis of the identified compounds was carried out; only the concentration of the active compound was estimated by the external standard method.

\subsection{Laboratory assay}

A four-well arena was used (Rosenkranz, 1993; Nazzi et al., 2001); the treatment dissolved in ether or acetone was applied to two opposite wells while the others were used as controls and treated with the solvent alone. After evaporation of the solvent one bee larva was placed into each well, then one adult female mite was placed in the centre of the arena at $1 \mathrm{~cm}$ from each well. The position of the mite was noted every 5 minutes; the bioassays lasted $30 \mathrm{~min}$ utes. Twenty arenas were used each time. Experiments were carried out at $35^{\circ} \mathrm{C}$ and $75 \%$ R.H.

The following experiments were carried out.

\subsubsection{Neutralization of the extract}

The biological activity of the acetone and ether extracts was tested before and after neutralization at $10 \mathrm{mg}$ equivalents in $10 \mu \mathrm{L}$ of solvent per well against acetone and ether respectively. Extracts were reduced to the desired concentration under a gentle stream of nitrogen. The experiment was 
replicated 5 times using a total of 100 mites in the case of the acetone extract and 2 times using a total of 40 mites with the ether.The carboxy-acids recovered after neutralization of the ether extract were tested at $10 \mathrm{mg}$ equivalents per well; the experiment was replicated 2 times using 40 mites.

\subsubsection{Air-entrainment extract}

The biological activity of the air-entrainment extract was tested at $10 \mathrm{mg} \times 1$ hour equivalents per well. The experiment was replicated 5 times using a total of 100 mites.

\subsubsection{Pure substances}

The following compounds were tested: 2-methylbutanoic acid, 3-methylbutanoic acid, 3-methylpentanoic acid, hexanoic acid, (Z)-3-hexenoic acid, 2-hydroxyhexanoic acid, 2-ethylhexanoic acid, benzoic acid, phenylacetic acid, octanoic acid, nonanoic acid; all experiments were replicated three times. Treated wells received $100 \mathrm{ng}$ of the compound dissolved in $10 \mu \mathrm{L}$ of ether; control wells received $10 \mu \mathrm{L}$ of ether only. The optical activity of 2-hydroxyhexanoic acid from larval food was not assessed and the racemic mixture was used for testing its biological activity. All compounds were purchased from Sigma-Aldrich.

2-Hydroxyhexanoic acid, showing activity at $100 \mathrm{ng}$ per well, was tested again at 1, 10, 100 and $1000 \mathrm{ng}$ (four further replications, a total of 80 mites at each dose); the isomer, 3-hydroxyhexanoic acid, was tested at 10, 100 and $1000 \mathrm{ng}$ (four replications, a total of 80 mites at each dose).

Seven further hydroxyl-carboxylic acids (2hydroxybutanoic acid, 3-hydroxybutanoic acid, 4hydroxybutanoic acid, 2-hydroxypentanoic acid, 2-hydroxyoctanoic acid, 8-hydroxyoctanoic acid, 10-hydroxydecanoic acid) were tested, 2 to 7 times, at $100 \mathrm{ng}$ per well.

\subsection{Hive bioassay}

2-Hydroxyhexanoic acid was tested in the hive by applying $100 \mathrm{ng}$ of the compound dissolved in $1 \mu \mathrm{L}$ of de-ionised water to worker brood cells containing 15 larvae, in an infested colony; a Hamilton syringe was used for applying the solution to brood cells. An equal number of cells was treated with $1 \mu \mathrm{L}$ of water and used as a control. The cells were marked on an acetate sheet for subsequent control. After 18 hours the sealed cells were opened and inspected; the number of mites in each cell was noted.

The experiment was replicated 5 times in August-September; on the whole, about 300 brood cells were considered for each experimental group.

\subsection{Statistical analysis}

For each arena, the number of times the mite was observed in the treated and control wells, respectively, over the 30 minutes period was calculated for being used as a score for the statistical analysis; thus, for a given arena, the score of treated and control wells can vary between 0 and 6 . For each replication, the scores of single arenas were summed; with 20 arenas, the scores can vary between 0 to 120. Then, a matrix was constructed with as many rows as the mites used in the bioassay, and two columns containing the scores for treated and control wells for each of the tested mites. The treatment and control scores in a given set of data were compared by a sampled randomization test (Manly, 1997; Sokal and Rohlf, 1995). The randomization distribution was resampled $10^{6}$ times with a computer program written for this purpose. A sampled randomization test was chosen because the distribution of the variables to be compared is unknown; in this case conventional parametric statistics often lead to overestimate the significance of differences.

The outcome of an experiment consisting of several replications was represented with the average score per replication.

The proportion of treated and control cells that were infested were compared using the MantelHaenszel method after testing the homogeneity in the odds ratios of the replicated $2 \times 2$ tables. The number of mites in treated and control brood cells, in the hive bioassay, were compared by a stratified sampled randomization test.

\section{RESULTS}

\subsection{Neutralization of the active extract}

Both total acetone and ether extracts were active on $V$. destructor, in that mites scored higher in treated wells compared to control ones (the difference between treated and control was significant in the case of the acetone extract and approached the 0.05 probability level in the case of the ether extract). The activity was lost after treatment with sodium bicarbonate (Tab. I). Carboxy-acids recovered from the neutralized extract did not show activity in the bioassay.

\subsection{Air-entrainment extract}

The air-entrainment extract of larval food attracted more mites to treated wells compared to control wells; the difference approached significance (Tab. I). 
Table I. Biological activity in the four-well arena of whole and neutralized acetone and ether larval food extracts and air-entrainment extracts. The average score per replicate is given.

n.s.: not significant $(P>0.10)$.

\begin{tabular}{|c|c|c|c|c|c|c|c|}
\hline \multirow{3}{*}{ stimulus } & \multirow{3}{*}{ replications } & \multicolumn{3}{|c|}{ total extract } & \multicolumn{3}{|c|}{ neutralized extract } \\
\hline & & \multicolumn{2}{|c|}{ scores } & \multirow{2}{*}{$P$} & \multicolumn{2}{|c|}{ scores } & \multirow{2}{*}{$P$} \\
\hline & & treated & control & & treated & control & \\
\hline acetone crude extract & 5 & 22.4 & 4.0 & $<0.001$ & 10.8 & 11.4 & n.s. \\
\hline ether crude extract & 2 & 15.0 & 6.0 & 0.086 & 11.0 & 12.5 & n.s. \\
\hline air-entrainment extract & 5 & 26.8 & 18.4 & 0.075 & & & \\
\hline
\end{tabular}

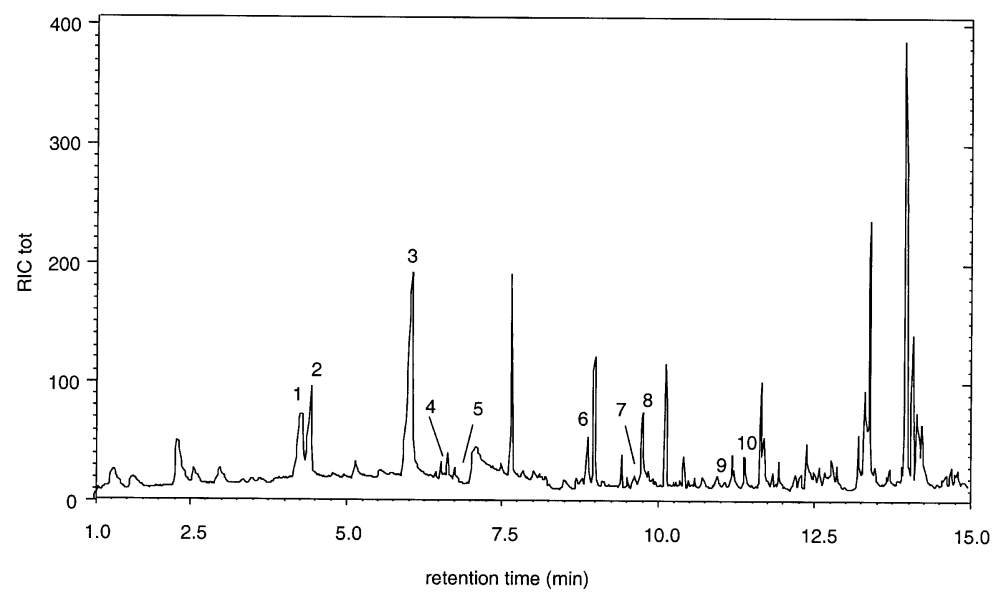

Figure 1. SPME-GC-MS analysis of drone larval food. 1: 3-methylbutanoic acid; 2: 2-methylbutanoic acid; 3: 2-methylpentanoic acid; 4: hexanoic acid; 5: hexenoic acid; 6: 2-ethylhexanoic acid; 7: benzoic acid; 8: octanoic acid; 9: phenylacetic acid; 10: nonanoic acid.

\subsection{Identification of larval food components}

Several low molecular weight carboxylic acids were identified in larval food by means of SPME-GC-MS (Fig. 1); GC-MS analysis of larval food extracts and GC-MS analysis of a larval food ether extract after derivatization confirmed the presence of most of these acids and allowed the identification of some hydroxyl carboxy-acids. Identified compounds were linear carboxy-acids (hexanoic, 3-hexenoic, octanoic and nonanoic acid), branched carboxy-acids (2-methylbutanoic, 3-methylbutanoic, 3-methylpentanoic and 2-ethylhexanoic acid), aromatic carboxy-acids (benzoic and phenylacetic acid) and hydroxyl carboxyacids (2-hydroxyhexanoic acid and other hydroxy-acids with 8 and 10 carbon atoms). Other non acidic compounds were revealed by the methods used here but, due to the results of the neutralization experiment, they were not further investigated.

\subsection{Bioassay of the compounds under laboratory conditions}

Most carboxy-acids did not show any activity on the varroa mite with nonsignificant differences between scores of treated and control wells. The movement of the mites in the assays of some compounds was rather scarce and thus the scores of both control and treated wells were low (Tab. II).

Only 2-hydroxyhexanoic acid showed biological activity on $V$. destructor at the concentration of $100 \mathrm{ng}$ per treated well and the difference between the scores of treated and control wells approached significance (Tab. II). The activity of 2-hydroxyhexanoic acid was confirmed in further tests carried out and appeared to be dose-dependent with the highest 
Table II. Biological activity of carboxy-acids identified in drone larval food, at $100 \mathrm{ng}$ per well. Three replications were carried out for each compound. The average score per replicate is given.

\begin{tabular}{lcccc}
\hline \multirow{2}{*}{ compound } & \multirow{2}{*}{ formula } & \multicolumn{2}{c}{ scores } & \multirow{2}{*}{$P$} \\
\cline { 3 - 4 } & & treated & control & \\
\hline 2-methylbutanoic acid & $\mathrm{C}_{5} \mathrm{H}_{10} \mathrm{O}_{2}$ & 8.0 & 13.3 & 0.850 \\
3-methylbutanoic acid & $\mathrm{C}_{5} \mathrm{H}_{10} \mathrm{O}_{2}$ & 21.3 & 25.7 & 0.719 \\
3-methylpentanoic acid & $\mathrm{C}_{6} \mathrm{H}_{12} \mathrm{O}_{2}$ & 8.3 & 7.3 & 0.444 \\
hexanoic acid & $\mathrm{C}_{6} \mathrm{H}_{12} \mathrm{O}_{2}$ & 28.7 & 31.7 & 0.636 \\
(Z)-3-hexenoic acid & $\mathrm{C}_{6} \mathrm{H}_{10} \mathrm{O}_{2}$ & 10.7 & 10.0 & 0.475 \\
2-hydroxyhexanoic acid & $\mathrm{C}_{6} \mathrm{H}_{12} \mathrm{O}_{3}$ & 30.3 & 18.3 & 0.079 \\
2-ethylhexanoic acid & $\mathrm{C}_{8} \mathrm{H}_{16} \mathrm{O}_{2}$ & 16.3 & 11.3 & 0.223 \\
benzoic acid & $\mathrm{C}_{7} \mathrm{H}_{6} \mathrm{O}_{2}$ & 21.3 & 18.7 & 0.413 \\
phenylacetic acid & $\mathrm{C}_{8} \mathrm{H}_{8} \mathrm{O}_{2}$ & 24.7 & 25.7 & 0.562 \\
octanoic acid & $\mathrm{C}_{8} \mathrm{H}_{16} \mathrm{O}_{2}$ & 16.3 & 13.7 & 0.344 \\
nonanoic acid & $\mathrm{C}_{9} \mathrm{H}_{18} \mathrm{O}_{2}$ & 10.0 & 16.0 & 0.863 \\
\hline
\end{tabular}

Table III. Biological activity of 2 and 3-hydroxyhexanoic acid at different doses in the four-well arena. Four replications were carried out for each dose. The average score per replicate is given.

\begin{tabular}{lcccc}
\hline \multirow{2}{*}{ compound } & \multirow{2}{*}{\begin{tabular}{c} 
dose \\
\cline { 3 - 4 }
\end{tabular}} & \multicolumn{2}{c}{ scores } & \\
\cline { 3 - 4 } & 1 & 22.3 & 23.5 & n.s. \\
2-hydroxyhexanoic & 10 & 36.0 & 17.3 & 0.008 \\
acid & 100 & 38.0 & 23.3 & 0.023 \\
& 1000 & 23.0 & 26.0 & n.s. \\
\hline \multirow{2}{*}{ 3-hydroxyhexanoic } & 10 & 24.5 & 21.8 & n.s. \\
acid & 100 & 36.8 & 22.8 & 0.042 \\
& 1000 & 23.3 & 22.5 & n.s. \\
\hline
\end{tabular}

response at 10 and $100 \mathrm{ng}$ (Tab. III). This amount roughly corresponds to $0.5-5$ drone cell equivalents.

The isomer 3-hydroxyhexanoic acid, differing from the former in the position of the hydroxyl group, showed some activity only at $100 \mathrm{ng}$ (Tab. III). None of the other hydroxyacids tested revealed any activity at $100 \mathrm{ng}$ (Tab. IV).

\subsection{Bioassay of the compounds under natural conditions}

When 2-hydroxyhexanoic acid was applied to natural cells 0-18 hours before capping, both the proportion of cells invaded by mites and the number of mites per cell were significantly higher in treated cells (Tab. V).

\section{DISCUSSION}

The actitvity of larval food extracts on the varroa mite under laboratory conditions confirmed previous data (Nazzi et al., 2001). The loss of biological activity after neutralization with sodium bicarbonate indicates that the active semiochemicals contained in larval food are acidic compounds. The lack of activity of the carboxy-acids recovered from the neutralized extract may be due to the reaction of other functional groups (e.g. the hydroxyl group) with the acid used in the process. The activity of the air-entrainment larval food extracts suggests that the active compounds are more or less volatile.

Because of the results of the experiments described above, attention was restricted to acidic, low molecular weight compounds. Several low molecular weight carboxylic acids, both linear, branched and aromatic, were identified by means of SPME-GC-MS analysis of larval food. The linear saturated carboxylic acids, hexanoic, octanoic and nonanoic acid, had already been reported in worker mandibular gland extracts and royal jelly distillates (Boch et al., 1979); the short branched carboxylic acids, isobutanoic and isopentanoic acid, may result from fermentation of larval food carbohydrates; benzoic and phenylacetic acid are already known as components of bee products (Speer and Montag, 1984).

GC-MS analysis of larval food crude extracts confirmed the presence of the hexanoic, octanoic, nonanoic and ethylhexanoic 
Table IV. Biological activity of some compounds related to 2-hydroxyhexanoic acid, at $100 \mathrm{ng}$ per well in the four-well arena. The average score per replicate is given.

\begin{tabular}{lccccc}
\hline \multirow{2}{*}{ compound } & \multirow{2}{*}{ formula } & replications & \multicolumn{2}{c}{ scores } & \multirow{2}{*}{$P$} \\
\cline { 4 - 5 } & & 7 & 20.0 & 19.9 & n.s. \\
\hline 2-hydroxybutanoic acid & $\mathrm{C}_{4} \mathrm{H}_{8} \mathrm{O}_{3}$ & 2 & 13.5 & 15.0 & n.s. \\
3-hydroxybutanoic acid & $\mathrm{C}_{4} \mathrm{H}_{8} \mathrm{O}_{3}$ & 2 & 14.5 & 15.5 & n.s. \\
4-hydroxybutanoic acid & $\mathrm{C}_{4} \mathrm{H}_{8} \mathrm{O}_{3}$ & 2 & 23.5 & 20.5 & n.s. \\
2-hydroxypentanoic acid & $\mathrm{C}_{5} \mathrm{H}_{10} \mathrm{O}_{3}$ & 2 & 29.5 & 29.5 & n.s \\
2-hydroxyoctanoic acid & $\mathrm{C}_{8} \mathrm{H}_{16} \mathrm{O}_{3}$ & 3 & 16.5 & 17.0 & n.s \\
8-hydroxyoctanoic acid & $\mathrm{C}_{8} \mathrm{H}_{16} \mathrm{O}_{3}$ & 2 & & 17.0 & n.s. \\
10-hydroxydecanoic acid & $\mathrm{C}_{10} \mathrm{H}_{20} \mathrm{O}_{3}$ & 3 & 24.0 & & \\
\hline
\end{tabular}

Table V. Proportion of infested cells and number of mites per cell in brood treated with $100 \mathrm{ng}$ of 2hydroxyhexanoic acid and in control cells.

\begin{tabular}{|c|c|c|c|c|c|c|}
\hline \multirow{2}{*}{ replication } & \multicolumn{2}{|c|}{ sealed cells } & \multicolumn{2}{|c|}{ infested cells } & \multicolumn{2}{|c|}{ mites/cell } \\
\hline & treated & control & treated & control & treated & control \\
\hline 1 & 77 & 89 & 0.19 & 0.20 & 0.27 & 0.22 \\
\hline 2 & 68 & 86 & 0.26 & 0.20 & 0.32 & 0.23 \\
\hline 3 & 79 & 78 & 0.29 & 0.18 & 0.30 & 0.26 \\
\hline 4 & 37 & 59 & 0.73 & 0.42 & 1.38 & 0.80 \\
\hline 5 & 41 & 37 & 0.51 & 0.51 & 0.73 & 0.70 \\
\hline average & & & 0.40 & 0.30 & 0.60 & 0.44 \\
\hline$P$ & & & \multicolumn{2}{|c|}{0.019} & \multicolumn{2}{|c|}{0.015} \\
\hline
\end{tabular}

acids detected by means of SPME-GC-MS analysis.

GC-MS analysis of crude extracts after derivatization revealed the presence of several hydroxy-acids. Most of them are already known as larval jelly components (Lercker et al., 1984). 2-Hydroxyhexanoic acid has not yet been reported either in larval food or as a component of the worker mandibular glands secretion. However, Engels et al. (1997) identified 3-hydroxyhexanoic acid among queen mandibular gland volatiles.

The dose-response relationship, with the highest response at quantities roughly corresponding to the ones found in the original source, as well as the fact that similar compounds were inactive, demonstrates that 2hydrohexanoic acid is a semiochemical active on $V$. destructor rather than an unspecific signal. The biological activity shown by 3 hydroxyhexanoic acid at $100 \mathrm{ng}$ may be due to the similarity of this compound to the active one.
The activity observed under natural conditions shows that 2-hydroxyhexanoic acid is involved in the process of cell invasion by the mite. The increase in the number of mites per cell in the treated brood seems to be related to a higher number of cells infested by mites rather than an increase in the number of mites per infested cell.

Attractants have been the subject of a number of studies in view of the possible use of such compounds for developing mite traps or just enhancing the efficacy of trap comb techniques. The compound identified here may well be employed for this purpose but the complex interactions between the parasite and its host, and particularly the fact that the mite does not reach the brood cell on its own, have to be taken into account. Alternative uses, such as those employed in pest-management using behavioural manipulation methods (Foster and Harris, 1997), should be considered as well.

Milani and Chiesa (1991) found that larval food has a positive effect on the reproduction 
of $V$. destructor under laboratory conditions; since arthropods tend to make a parsimonious use of semiochemicals (Blum, 1996) further investigation on the effect of 2-hydroxyhexanoic acid on the oogenesis and/or oviposition of the parasite may be interesting.

The existence of semiochemicals from larval food involved in the process of cell invasion by the mite should induce reconsideration of the methods used to compare the "attractiveness of bee brood" by grafting larvae of different origins into the same colony (e.g. Büchler, 1990). This technique may lead to differences being overlooked, since all the larvae receive food from the nursing colony; conversely, different feeding of larvae of various origins could result in different infestation rates.

Further studies concerning the changes of larval food composition with the age of larva and worker food composition will determine whether the higher attractiveness of drone cells and the timing of the process of cell invasion are related to the amount of 2hydroxyhexanoic acid in $14 / 15$ worker and drone larvae.

Résumé - Un composé sémiochimique de la nourriture larvaire influence la pénétration de Varroa destructor dans les cellules de couvain. L'acarien Varroa destructor pénètre dans les cellules de couvain entre 0 et $40 \mathrm{~h}$ avant l'operculation. Plusieurs facteurs déclenchent ce comportement, parmi lesquels des signaux chimiques. Cette étude vise à identifier les stimuli chimiques, présents dans la nourriture des larves de mâles, qui agissent sur l'acarien. L'activité biologique de différents stimuli a été évaluée à l'aide d'un test biologique : on a étudié le déplacement d'un acarien dans une arène en verre munie de quatre puits traités ou non avec les substances à tester. Il a été récemment montré que l'acarien préférait les puits traités avec la nourriture de larve de mâles ou avec ses extraits. Les extraits de nourriture larvaire perdent leur activité biologique après neutralisation au bicarbonate de sodium, ce qui suggère que les composés attractifs sont des composés acides (Tab. I). Les composés volatils émis par la nourriture larvaire et extraits d'un polymère poreux sur lequel ils avaient été entraînés, ont déclenché une réponse positive de $V$. destructor, ce qui suggère que les composés actifs sont volatils (Tab. I). Différentes méthodes analytiques ont permis d'identifier plusieurs composés acides, parmi lesquels des acides gras saturés linéaires et branchés, des acides carboxyliques aromatiques et des acides gras hydroxylés. Ils étaient tous inactifs sauf l'acide hydroxy-2-hexanoïque, pour lequel les aca- riens sont entrés en plus grand nombre dans les puits traités (Tab. II). Des tests complémentaires avec diverses doses ont confirmé l'activité biologique de ce composé à des doses équivalant à $0,5-$ 5 cellules (Tab. III). Si, avant l'operculation, on applique le composé à l'intérieur des cellules de couvain qui renferment des larves, on observe une augmentation du nombre d'acariens par cellule de $36 \%$ par rapport au témoin traité avec le solvant seul (Tab. V). D'autres études sont nécessaires pour vérifier si l'acide hydroxy-2-hexanoïque est potentiellement utilisable pour lutter contre $V$. destructor.

Varroa destructor / composé sémiochimique / nourriture larvaire / acide hydroxy-2-hexanoïque / invasion des cellules

Zusammenfassung - Ein Botenstoff aus der Larvennahrung lockt Varroa destructor in Brutzellen. Die Milbe Varroa destructor dringt 0-40 Stunden vor der Zellverdeckelung in die Brutzellen ein. Das Verhalten wird durch verschiedene Faktoren ausgelöst, unter diesen wurden chemische Reize in Betracht gezogen. Vor kurzer Zeit konnte in einem Labortest gezeigt werden, dass in den Brutzellen enthaltene Larvennahrung das Fortbewegungsverhalten des Parasiten beeinflusst. Die vorliegende Studie zielt auf die Bestimmung der in der Larvennahrung enthaltenen auf die Milben aktiven chemischen Reize ab. Die biologische Aktivität von verschiedenen Reizen wurde mit einem Biotest ermittelt, in dem das Fortbewegungsverhalten der Milben in einer Glasarena mit vier entweder mit den zu testenden Reizen behandelten oder unbehandelten Vertiefungen mit jeweils einer Bienenlarve erfasst wurde. Die Extrakte der Larvenahrung verloren ihre biologische Aktivität nach Neutralisation mit Natriumbikarbonat, dies weis darauf hin, dass die attraktiven Substanzen saure Komponenten sind (Tab. I). Die von der Larvennahrung freigesetzten flüchtigen Substanzen, die von einem porösen Polymer aufgenommen und dann extrahiert wurden, lösten eine positive Reaktion von $V$. destructor aus. Dies weist darauf hin, dass die aktiven Substanzen flüchtig sind (Tab. I). Einige der sauren Komponenten, darunter unverzweigte und verzweigte Fettsäuren, aromatische Karboxylsäuren und Hydrolylfettsäuren wurden mit unterschiedlichen Techniken identifiziert. 2-Hydroxyhexanoische Säure verursachte, dass mehr Milben in den Labortests die behandelten Vertiefungen betraten (Tab. II). Weitere Tests mit unterschiedlichen Dosierungen bestätigten die biologische Aktivität dieser Komponente in Dosierungen von 0,5 bis 5 Zelläquivalenten (Tab. III). Wenn die Komponente vor der Zellverdeckelung in das Innere von Brutzellen mit Larven eingebracht wurde, erhöhte dies die Anzahl von Milben pro Zelle um $36 \%$ im Vergleich zu Zellen, die nur mit Lösungsmittel behandelt waren (Tab. IV). Weitere Untersuchungen sollen zeigen ob die Substanz ein Potential zur Bekämpfung der Milben hat. 
2-Hydroxyhexanoische Säure / Attraktion / Larvennahrung / Botenstoffe / Varroa destructor

\section{REFERENCES}

Aumeier P., Rosenkranz P. (1995) Welche Faktoren der Bienenlarvenkutikula beeinflussen die Wirtsfindung der Varroa-Weibchen, Apidologie 26, 327-329.

Bee World (1975) What we know about pollen, Bee World 56, 155-158.

Blomquist G.J., Chu A.J., Remaley S. (1980) Biosynthesis of wax in the honeybee, Apis mellifera L., Insect Biochem. 10, 313-321.

Blum M.S. (1996) Semiochemical parsimony in the Arthropoda, Annu. Rev. Entomol. 41, 353-374.

Boch R., Shearer D.A., Shuel R.W. (1979) Octanoic and other volatile acids in the mandibular glands of the honeybee and in royal jelly, J. Apic. Res. $18,250-253$.

Boot W.J., Calis J.N.M., Beetsma J. (1992) Differential period of Varroa mite invasion into worker and drone cells of honey bees, Exp. Appl. Acarol. 16, 295-301.

Büchler R. (1990) Möglichkeiten zur Selektion auf erhöhte Varroa-Toleranz mitteleuropäischer Bienenherkünfte, Apidologie 21, 365-367.

Calderone N.W., Lin S. (2001) Behavioural responses of Varroa destructor (Acari: Varroidae) to extracts of larvae, cocoons and brood food of worker and drone honey bees, Apis mellifera (Hymenoptera: Apidae), Physiol. Entomol. 26, 341-350.

Chiesa F., Milani N., D’Agaro M. (1989) Observations of the reproductive behaviour of Varroa jacobsoni Oud.: techniques and preliminary results, Present status of varroatosis in Europe and progress in the varroa mite control, Proc. Meeting EC-Experts Group, Udine 1988, in: Cavalloro R. (Ed.), C.E.C., Luxembourg, pp. 213-222.

Comparini A., Biasiolo A. (1991) Genetic discrimination of Italian bee, Apis mellifera ligustica versus Carniolan bee, Apis mellifera carnica by allozyme variability analysis, Biochem. Syst. Ecol. 19, 189-194.

Crane E. (1979) Honey. A comprehensive survey, Heinemann, London.

Engels W., Rosenkranz P., Adler A., Taghizadeh T., Lübke G., Francke W. (1997) Mandibular gland volatiles and their ontogenetic patterns in queen honey bees, Apis mellifera carnica, J. Insect Physiol. 43, 307-313.

Francis B.R., Blanton W.E., Nunamaker R.A. (1985) Extractable surface hydrocarbons of workers and drones of the genus Apis, J. Apic. Res. 24, 13-26.

Foster S.P., Harris M.O. (1997) Behavioral manipulation methods for insect pest-management, Annu. Rev. Entomol. 42, 123-146.

Kraus B. (1993) Preferences of Varroa jacobsoni for honey bees (Apis mellifera L.) of different ages, J. Apic. Res. 32, 57-64.
Le Conte Y., Arnold G., Trouiller J., Masson C., Chappe B., Ourisson G. (1989) Attraction of the parasitic mite Varroa jacobsoni to the drone larvae of honeybees by simple aliphatic esters, Science 245, 638-639.

LeDoux M.N., Pernal S.F., Higo H.A., Winston M.L. (2000) Development of a bioassay to test the orientation behaviour of the honey bee ectoparasite Varroa jacobsoni, J. Apic. Res. 39, 47-54.

Lercker G., Vecchi M.A., Piana L., Nanetti A., Sabatini A.G. (1984) Composition de la fraction lipidique de la gelée de larves d'abeilles reines et ouvrières (Apis mellifera ligustica Spinola) en fonction de l'âge des larves, Apidologie 15, 303314.

Manly B.F.J. (1997) Randomization, bootstrap and Monte Carlo methods in biology, Chapman and Hall, London.

Marcucci M.C. (1995) Propolis: chemical composition, biological properties and therapeutic activity, Apidologie 26, 83-99.

Milani N., Chiesa F. (1991) Some stimuli inducing oviposition in Varroa jacobsoni Oud, Proc. Int. Symp. Recent research on bee pathology, Gent 1990, in: Ritter W. (Ed.), Apimondia, Bucharest, pp. 27-33.

Nazzi F. (1992) Morphometric analysis of honey bees from an area of racial hybridization in northeastern Italy, Apidologie 23, 89-96.

Nazzi F., Milani N., Della Vedova G., Nimis M. (2001) Semiochemicals from larval food affect the locomotory behaviour of the varroa mite, Apidologie 32, 149-155.

Rickli M., Diehl P.A., Guerin P.M. (1994) Cuticle alkanes of honeybee larvae mediate arrestment of bee parasite Varroa jacobsoni, J. Chem. Ecol. 20, 2437-2453.

Rickli M., Guerin P.M., Diehl P.A. (1992) Palmitic acid released from honeybee worker larvae attracts the parasitic mite Varroa jacobsoni on a servosphere, Naturwissenschaften 79, 320-322.

Rosenkranz P. (1993) Biotest zur Untersuchungen des Wirtsfindenverhaltens von Varroa jacobsoni, Apidologie 24, 486-488.

Sokal R.R., Rohlf F.J. (1995) Biometry: The Principles and Practice of Statistics in Biological Research, Freeman and Co., New York.

Speer K., Montag A. (1984) Occurrence of benzoic acid and phenylacetic acid in honey, Dtsch. Lebensmittel Rundsch. 80, 103-105.

Sweeley C.C., Bentley R., Makita M., Wells W.W. (1963) Gas-liquid chromatography of trimethylsilyl derivatives of sugars and related substances, J. Am. Chem. Soc. 85, 2497-2507.

Tulloch A.P. (1980) Beeswax - composition and analysis, Bee World 61, 47-62.

Zetlmeisl K., Rosenkranz P. (1994) Varroa-Weibchen im Biotest: Wirtserkennung von Bienenlarven und adulten Bienen, Apidologie 25, 507508. 